\title{
Education for excellence in professional nursing practice
}

A new year and a new beginning. At the end of November 2015, I returned from participating in the $43^{\text {rd }}$ Biennial Convention of the prestigious global Nursing Society, Sigma Theta Tau International (STTI). With over 2,500 nurses from education, practice and research and from all parts of the globe, it was an inspirational experience. The event itself as the name implies, occurs every two years, every alternate year in the home city of Indianapolis where the society is based and alternating in another city in the United States of America (USA). This year it was in Las Vegas, Nevada. However, the focus was not on the casinos or the flashing neon lights but on the scholarship of Nursing, of networking with our colleagues from around the world and from learning from each other. The convention has become the 'single most visible embodiment of the STTI mission; Advancing world health and celebrating nursing excellence in scholarship, leadership and service" (STTI, 2015, p5). I would recommend the event to you all.

It was notable to witness the different cultural approaches to nursing practice and education. The American nurses are in awe of the UK's 'all-graduate' intakes of students onto programmes leading to professional registration. And, whilst they recognise that they are a long way themselves from achieving this, they do present a confidence and an openness about what they do offer and how far they have developed in bringing their education, scholarship and practice together and are keen to celebrate their success. Some were particularly proud of their institution's achievement of Magnet status and increasingly this is something being considered by nurses and hospitals in the UK. Introduced in the 1990s in the USA at a time of a national nursing shortage, Magnet status recognises the quality of patient care and focuses on recognising "nursing excellence and innovations in professional nursing practice" (ANCC 2015). The Magnet Award measures five 'components':

- Transformational Leadership

- Structural Empowerment

- Exemplary Professional Practice

- New Knowledge, Innovation and Improvements

- Empirical Quality Results

Magnet status has grown in popularity since this time, with over 400 accredited institutions in the USA, although representing only $7 \%$ of USA hospitals (RCN 2015). Outside of the USA, only 8 institutions globally hold Magnet status and none within Europe (RCN 2015).

After the publication of the most recent Francis Report (2013), there has been increasing interest in Magnet status in the UK. Indeed, Lord Willis recommends (2015, p64) in his review of the future education and training of registered nurses and care assistants, the establishment of an expert group "to examine the potential implications of developing and implementing Magnet principles to improve the education of the workforce and patient outcomes". Implementing Magnet principles would certainly be a more manageable concept for UK nurses than formal application for Magnet Award. Formal application requires an ongoing and very costly process to achieve and maintain and I would argue, divert the energies of the NHS away from its focus on care to produce the considerable effort collecting and processing a large amount of data including the educational achievement of 
all its nursing staff. Nevertheless, in spite of some criticisms of the Magnet Award (RCN 2015), there is no doubt that some USA healthcare organisation have invested heavily in achieving the award and the perceived benefits are evidenced in the increasing number of organisations seeking Magnet status.

With all the bad press that UK nursing has received in recent years, in order to retain its current workforce and encourage new recruits (especially in light of the recent Comprehensive Spending Review and introduction of student loans), a national initiative such as the Magnet Award for institutions may offer a manageable solution. Clearly Lord Willis believes there is a feasibility that needs to be considered to 'raise the bar' in terms of evidencing the quality of nursing care and encouraging all non-graduates to study further to gain graduate recognition. The educational achievement of the nursing workforce is clearly prised, and Magnet status is one way of evidencing this more widely. Indeed Aiken et al (2014), in their large European study demonstrated a lower patient mortality in institutions with a high graduate nursing workforce than those with lower nursing qualifications. It may be that Aitken et al's current focus on the USA may well provide more substantial evidence to link Magnet status with improvements in outcomes across care settings and better work environments for nurses (RCN 2015).

So, I would argue that education matters. Whether the UK follows our American colleagues in seeking the Magnet Award, or simply looks to their criteria for such status, recent reports certainly point to the need to support registered nurses in their achievement of graduate recognition (Willis 2015, Aiken et al 2014). Additionally, with the high registered:nurse assistant staff ratio, there is much to do nationally to raise the qualifications of care assistants (to Care Certificate or equivalent) and to make them mandatory.

There certainly seems to be a common vision between the goals of the Magnet Award and goals for the UK nursing workforce. Investment in nursing leadership, advancing nursing skills and competencies as well as the drive to improve the educational achievement and career progression routes for nursing staff are all common characteristics. However, whilst commendable, I would argue that we need to find a way of adopting the principles of achieving and maintaining such an award and avoid the huge costs, to focus our energies on what is important, education for excellence in professional nursing practice.

Words: 913

\section{References}

Aiken, L.A., Sloane, D.M., Bruyneel, L., Van den Heede, K., Griffiths, P., Busse, R., Diomidous, M., Kinnunen, J., Kózka M., Lesaffre, E., McHugh, M.D., Moreno-Casbas, M.T., Rafferty, A.M., Schwenndimann, R., Scott, P.A., Tishelman, C., van Achterberg, T., Sermeus W. (2014) Nurse staffing and education and hospital mortality in nine European countries: a retrospective observational study. The Lancet, 383(9931) 1824-1830.

American Nurses Credentialling Center (2015) Magnet Recognition Program Overview. Accessed on 2.1.16 at http://www.nursecredentialing.org/Magnet/ProgramOverview

Cavendish, C 2013 The Cavendish Review: An Independent Review into Healthcare Assistants and Support Workers in the NHS and social care settings. July, Accessed on 15.12.15 at 
https://www.gov.uk/government/uploads/system/uploads/attachment data/file/236212/Caven dish Review.pdfew.pdf

Francis R. (2013) The final report of the Mid Staffordshire NHS Foundation Trust Public Inquiry. February, The Stationery Office, London

Royal College of Nursing 2015 The Magnet Recognition Programme: a discussion of its development, success and challenges for adoption in the UK. RCN Policy and International Department: Discussion Paper 09/2015, July.

Sigma Theta Tau International 2015) $43^{\text {rd }}$ Biennial Convention Programme Book. 7-11 November. Accessed at www.nursingsociety.org

Willis P. 2015 Raising the Bar: The Shape of Caring: A Review of the Future Education and Training of Registered Nurses and Care Assistants. Health Education England, London,

Words: 1,111

Professor Elizabeth Rosser

Bournemouth University, 2.1.16 